\title{
Cockroach tergal glands producing female sex attractant pheromones and male aphrodisiacs in particular in the subfamily Blaberinae (Blattaria: Blaberidae)
}

\author{
LEAM SRENG \\ Laboratoire de Neurobiologie des Processus Mnésiques (Neurobiologie Intégrative et Adaptative, NIA), UMR 6149, \\ CNRS-Université de Provence, Centre St Charles, Pole 3C, Bat 9-case B, 3 Place Victor Hugo, 13331 Marseille Cedex 03, France; \\ e-mail: leam.sreng@up.univ-mrs.fr
}

Key words. Blattaria, Blaberidae, Blattodea, cockroach, evolution, exocrine gland, mating behavior, pygidial gland, sex pheromone regulation, tergal gland, type 3 gland cell

\begin{abstract}
Two principal pheromones are essential in all cockroach sexual behavioral sequences: the volatile sex attractant pheromone released by one partner for long distance attraction and an aphrodisiac sex pheromone produced exclusively by male tergal glands for female mounting and feeding behavior. In the Blaberinae subfamily, the female produces volatile sex attractant pheromones and the male, aphrodisiacs. A close relationship is known to exist between the release of these pheromonal signals from specific glands and the corresponding behaviors (female calling posture and male wing raising). However, in this cockroach group, no data on the glands secreting sex attractant pheromones and aphrodisiacs have been available until now. In seven species of the Blaberinae subfamily: Blaberus colosseus, B. craniifer, B. discoidalis, Blaptica interior, Byrsotria fumigata, Eublaberus distanti and E. posticus; one species of the Zetoborinae subfamily: Schultesia lampyridiformis; one species of the Epilamprinae subfamily: Epilampra maya and one species of the Panesthiinae subfamily, Panesthia sp., the females possess all pygidial glands on the $10^{\text {th }}$ tergite and the males have tergal glands situated anteriorly, generally on tergites T1 and T2. These glands are formed of type 3 glandular units with two cells, i.e. glandular and canal cells. The uniform presence of female pygidial glands and male tergal glands explains their relationship with their corresponding sexual behaviors.
\end{abstract}

\section{INTRODUCTION}

Among cockroaches, chemical signals play a fundamental role in two important phases of their sexual behavioral sequences: attracting a sexual partner and mating behavior (courtship and mating). Two essential chemicals are involved during these two major phases: the volatile sex attractant pheromone for long distance attraction, emitted by one of the sexual partners (male or female) and the aphrodisiac sex pheromone or "aphrodisiac", secreted exclusively by male tergal glands in most cases, for female mounting and feeding behavior. The release of these pheromonal signals from the glands is in close connection with the corresponding behaviors such as calling posture or male wing raising.

Three patterns of mating behavior were distinguished in this insect group (Sreng, 1993): (i) type A pattern (female in upper position) - male wing-raising display, female mounting, and tergal contact on the male's back, where the male pushes his abdomen under the female to make connection with her genitalia and the copulating pair adopts an opposite position; (ii) type B pattern (male in upper position) - no male wing raising, the male mounts the female's back, twists his abdomen under that of the female and makes contact with the female's abdominal tip, copulation end-to-end and (iii) type $\mathrm{C}$ pattern (male and female end to end) - the male neither raises the wings nor mounts the female, but backs toward the female to copulate end-to-end.

Unlike other cockroach groups, males of the Oxyhaloinae species (Blaberidae Brunner von Wattenwyl, 1865) produce both chemical signals, sex attractant pheromone secreted by the sternal glands and aphrodisiac secreted by the tergal glands (Sreng, 1984). In Nauphoeta cinerea Olivier, the male adopts a calling pose, similar to an aggressive posture (Ewing, 1967), exposing sternal glands that attract females from a distance (Sreng, $1979 b)$. After the meeting of the sexes, the male releases an aphrodisiac from the tergal glands (Roth, 1969; Brossut \& Roth, 1977; Sreng, 1979a, 1983) by performing characteristic wing raising movements, revealing the tergal glands that induce females to mount and lick them (Roth \& Willis, 1952; Roth \& Barth, 1967; Simon \& Barth, 1977a, b; Bell, 1981; Sreng, 1979b).

In many other cockroach species, the female releases a sex pheromone: the virgin female assumes the "calling posture" (Willis, 1970; Schal, 1982; Hales \& Breed, 1983; Schal et al., 1984; Schal \& Bell, 1985), raises her wings and exposes the intertergal membrane or expands the genital chamber, but the exact positions of the glands is unknown. The calling female Periplaneta americana Linnaeus (Blattidae: Blattinae) expands her genital chamber (Sreng, 1983; Abed et al., 1993b). In the field, only calling females attract one or more males over a distance of 24-28 m (Seelinger, 1984). In Supella longipalpa Fabricius (Blattellidae: Pseudophyllodromiinae), the site of sex pheromone production was localized to the fourth and fifth abdominal tergites (Schal et al., 1992). In Blattella germanica Linnaeus (Blattellidae: Blattellinae), female calling behavior is observed (Liang \& Schal, 1993a) and female sex pheromone was recently identified (Nojima et al., 2005) from the last abdominal tergite or 
pygidium glands (Dusham, 1918; Brossut \& Roth, 1977; Sreng, 1983; Tokro, 1984; Tokro et al., 1993; Abed et al., 1993c; Liang \& Schal, 1993b, c). However, after male and female meet, the characteristic behavior of the male releasing aphrodisiac from the tergal glands (Roth 1969; Brossut \& Roth, 1977; Sreng, 1983) is evident by male wing raising, revealing the tergal glands that attract females to mount, "feed" or "lick" them (Roth \& Willis, 1952, 1954; Roth \& Barth, 1967; Bell, 1981; Sreng, $1979 \mathrm{a}, \mathrm{b})$.

Only the distinctive cuticular modifications of male abdominal glands of cockroaches, such as tufts of setae, ridges and fossae, were considered as being indicative of tergal glands (Roth, 1969; Brossut \& Roth, 1977). Actually, male tergal glands were present on male tergites with no distinctive cuticular modifications but with numerous open glandular orifices (Sreng, 1979b, 1983, 1984, 1985) and considered as type 3 glandular cell units (Noirot \& Quennedey, 1974, 1991).

The ontogenesis of these glandular cells was studied in the male abdominal glands of $B$. germanica and $N$. cinerea. Pheromonal gland differentiation begins before the imaginal moult with the formation of a basic glandular unit of four cells and ends 3-4 days after with only two cells (Sreng, 1976, 1985, 1998; Sreng \& Quennedey, 1976; Quennedey, 1998). Pheromone production in glandular epithelium equipped with type 3 cells is closely related to gland maturation (Sreng et al., 1999), governed by brain factors (Sreng, 1998).

This work describes the morphology of female pygidial glands and male tergal glands whose secretions (sex attractant pheromones and aphrodisiacs) play a fundamental role in precopulatory sexual behavior among seven species of the Blaberinae subfamily (Blaberidae): Blaberus colosseus Illiger, 1801, B. craniifer Burmeister, 1838, B. discoidalis Serville, 1839, Blaptica interior Hebard, 1921, Byrsotria fumigata Guérin, 1857, Eublaberus distanti Kirby 1903, E. posticus Erichson, 1848 , one species of the Zetoborinae subfamily (Blaberidae): Schultesia lampyridiformis Roth, 1973, one species of the Epilamprinae subfamily (Blaberidae): Epilampra maya Rehn, 1902, and one species of the Panesthiinae subfamily (Blaberidae): Panesthia sp. Serville, 1831 according to the classification of McKittrick (1964) and Grandcolas (1996). These exocrine glands in many species were first described in my previous investigations (Sreng, 1983). As there were many similarities in the organization, morphology and structure of female pygidial and male tergal glands, only some species analysed with specific techniques were presented. The mating behavior of many species of this cockroach group has been described in previous studies by several authors (Barth, 1964, 1968; Grillou, 1973; Roth, 1968, 1970b). They demonstrated that receptive females released sex pheromone attracting males from a distance and eliciting male wing raising to reveal tergal regions that incite females to mount and lick the males back before copulation occurs. These cockroach species belong principally to the type A pattern of mating behavior where sex attrac- tant pheromone is emitted by the female. The evolutionary significance of glandular morphology and behavior, sex pheromone regulation in relationship with glandular unit maturation and chemical pheromonal compounds of some cockroach groups will be discussed.

\section{MATERIALS AND METHODS}

\section{Insects}

Colonies of the cockroaches: Blaberus craniifer, Byrsotria fumigata, Eublaberus distanti, E. posticus, Schultesia lampyridiformis were maintained in $27 \times 28 \times 45 \mathrm{~cm}$ terraria at $27^{\circ} \mathrm{C}$ under a 12L : 12D photocycle with access to dry dog food and water. Some specimens, such as Blaberus colosseus, B. discoidalis, Blaptica interior, Epilampra maya and Panesthia sp. came from collections offered by Dr. L.M. Roth, U.S. Army Natick Laboratories, Natick, Massachusetts. Only the adult males and females were used in microscopy preparations.

\section{In toto preparation}

The adult abdominal tergites and sternites were dissected along the pleural membranes, freed of underlying tissue by treatment in solution of $10 \% \mathrm{KOH}$. After several rinses in water and dehydration in alcohol, the specimens were mounted in a Canada balsam medium. The preparations were examined, photographed under a Leitz photomicroscope and the glandular orifices counted per $\mathrm{mm}^{2}$ in the photographs. The glandular zones were determined according to the density of glandular orifices in the area of each tergite and pygidium. For each species, the number of glandular orifices or depressions were an average of three counts.

\section{Scanning electron microscopy}

Adult abdominal tergite and sternite bearing glands were dissected, dehydrated in alcohol and coated with a layer of gold by vacuum sublimation. The preparations were examined using a scanning electron microscope, Jeol SEM 6320F.

\section{Histology}

The techniques used were those described in Martoja \& Martoja-Pierson (1967). Following alcoholic Bouin's fixation, after dehydration and paraffin embedding, the preparations were sectioned at $7 \mu \mathrm{m}$ and stained with Masson's Trichrome.

\section{Ultrastructure}

The methods used for ultrastructural studies of pygidial glands of B. fumigata have been described previously (Sreng, 1979a, 1985, 1998). Gland fixation was carried out in a solution of $2 \%$ glutaraldehyde in $0.1 \mathrm{M}$ cacodylate buffer $(\mathrm{pH} 7.4)$ for 16 $\mathrm{h}$ at $4^{\circ} \mathrm{C}$, followed by a postfixation of $1 \mathrm{~h}$ at $4^{\circ} \mathrm{C}$ using osmium tetroxyde in the same buffer. Pygidial gland pieces were dehydrated in increasingly pure ethanol solutions, followed by propylene oxide, and embedded in Epon-Araldite resin. Sections were contrasted with a solution of uranyl acetate in $50 \%$ ethanol, then in lead citrate.

\section{RESULTS}

\section{Female and male abdominal glands}

\section{Byrsotria fumigata}

Female pygidial glands. Females possess pygidial glands situated on the anterior zone of T10 (Figs 1, 2) with a surface area of about $1 \mathrm{~mm}^{2}$, and tergal glands on T9, less developed but more widespread, with a total glandular surface area of about $2.8 \mathrm{~mm}^{2}$. In T9, glandular orifices were solitary with no depressions and averaging 

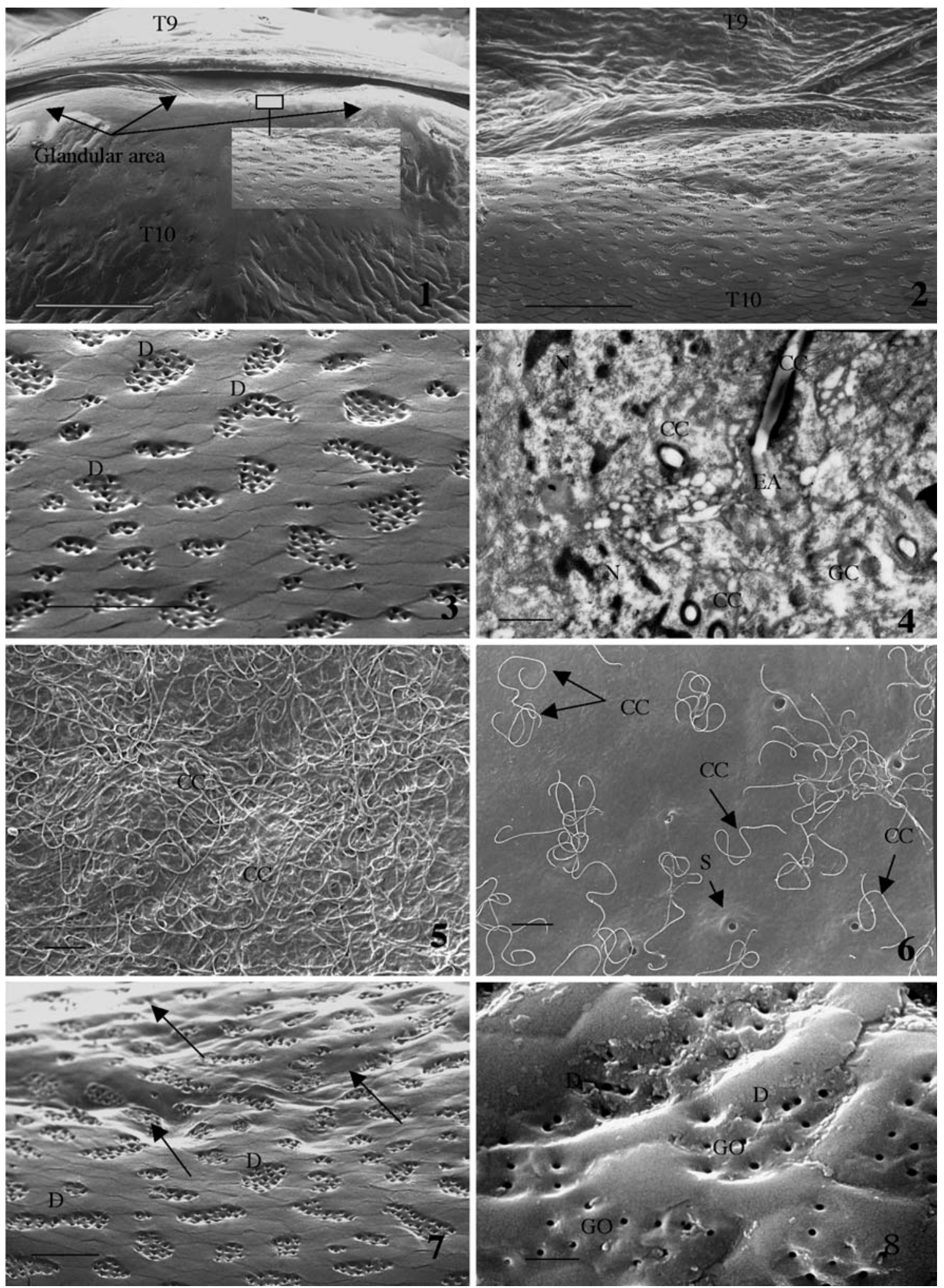

Figs 1-8. 1-2: Byrsotria fumigata female. 1 - dorsal view of tergites T9 and T10 (pygidium) which show the glandular area (arrows) on the anterior part of pygidium. Detail of a small area of the glandular region (small rectangle) with numerous glandular depressions with open glandular orifices. Bar $=1 \mathrm{~mm} .2$ - dorsal view of tergites T9 and T10 (pygidium) which show the intertergal membrane joining segment T9 and pygidium (T9, T10). Glandular region on the anterior part of the pygidium (undulating and slacking region) which contain numerous glandular depressions. Bar $=100 \mu \mathrm{m}$. Figs 3-7: Byrsotria fumigata female. 3 - detail of glandular area showing depressions of various sizes and shapes (D) with numerous open glandular orifices. Bar $=40 \mu \mathrm{m} .4$ - with transmission electron microscopy, longitudinal section of a duct (CC) inserted into the glandular cell (GC) with end apparatus (EA). $\mathrm{N}=$ nucleus. Bar $=1.5 \mu \mathrm{m} .5$ - internal face on the anterior part of the $\mathrm{T} 10$ after cells were removed by $\mathrm{KOH}$ treatment revealing numerous ducts $(\mathrm{CC})$. Bar $=20 \mu \mathrm{m} .6-$ internal face on the posterior part of T10 revealing scarce ducts but entire duct and end apparatus (CC); setae (S) with large orifice opening into the cuticle. Bar $=20 \mu \mathrm{m} .7-$ anterior part of pygidium with undulating and slacked area (arrows) containing numerous depressions (D) and glandular orifices. In normal position, this part was hidden by T9. Bar $=20 \mu \mathrm{m} .8$ - Blaberus craniifer female. Detail of glandular area of the anterior part of pygidium showing depressions (D) containing numerous glandular orifices (GO). Bar $=5 \mu \mathrm{m}$. 

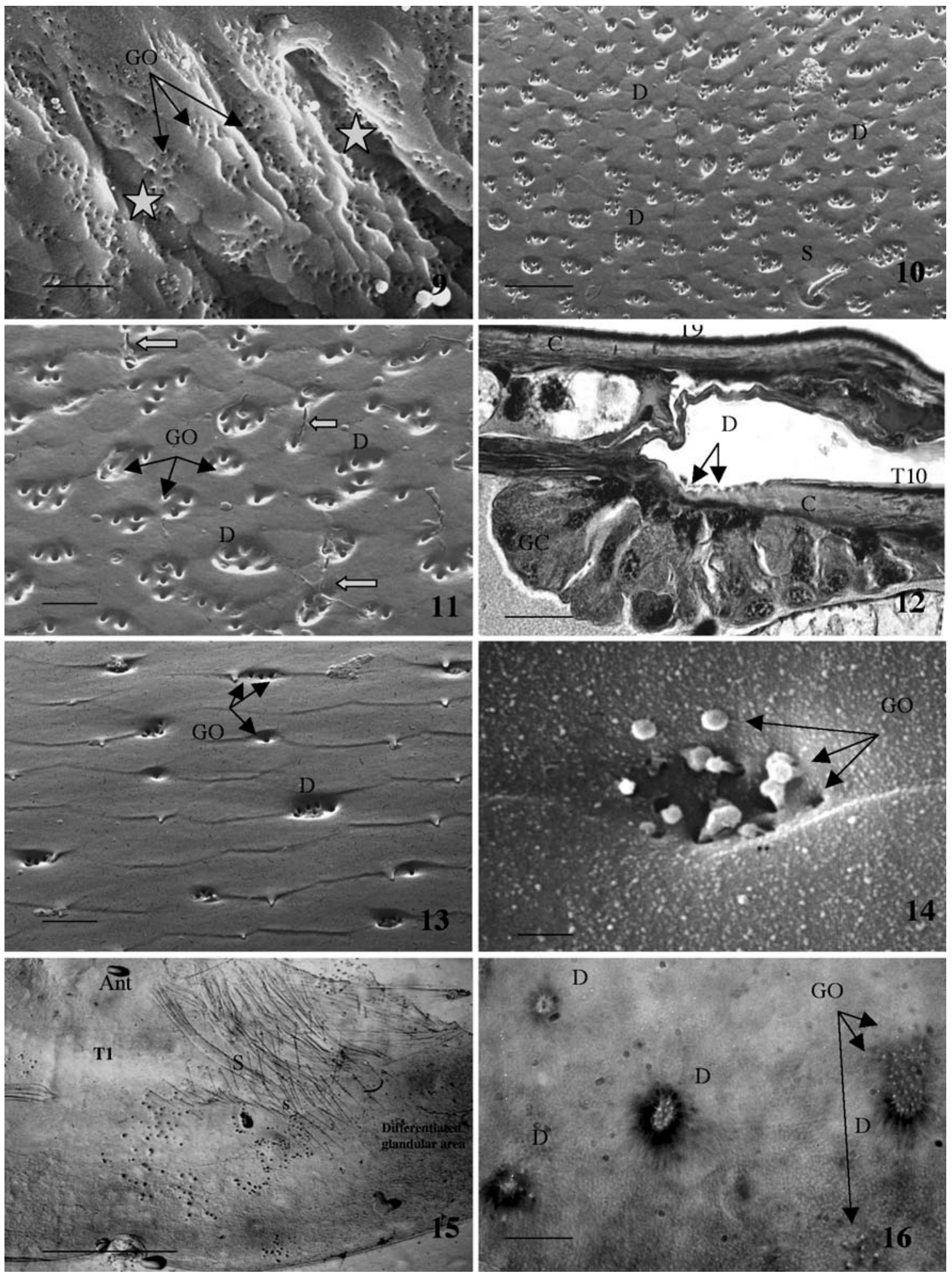

Figs 9-16. 9 - Blaberus craniifer female. Numerous glandular orifices (GO) were open in the prominent undulating area (asterisk) of the anterior part of tergite T10. Bar $=20 \mu \mathrm{m} .10-11$ : Blaptica interior female. 10 - glandular orifices were open in variable, small depressions (D) located in the anterior part of the pygidium. $\mathrm{S}=$ setae. Bar $=20 \mu \mathrm{m} .11$ - detail of depressions containing glandular orifices (GO). Some orifices were filled with threadlike material (arrow). Bar $=6 \mu \mathrm{m} .12-$ Schultesia lampyridiformis female. Longitudinal section through tergites T9 and T10 showing the intertergal membrane joining segment T9 and pygidium, glandular epithelium with depressions (D) on the cuticle (C) and numerous glandular cells (GC) on the bottom. Bar $=20 \mu \mathrm{m}$. 13, 14: Byrsotria fumigata male, SEM. 13 - general appearance of the tergal gland on T2. Glandular orifices (GO) open in variable depressions (D). Bar $=4 \mu \mathrm{m} .14$ - detail of some glandular orifices of tergal gland T2, open in a cuticular depression with mushroom-like secretions growing from numerous glandular orifices (GO). Bar $=2 \mu \mathrm{m} .15,16$ : Byrsotria fumigata male, optical microscope. 15 differentiated glandular area of T1. S = sensory setae. Ant = anterior part of the tergite. Bar $=1 \mathrm{~mm} .16-$ detail of differentiated glandular area showing depressions (D) containing numerous glandular orifices (GO). Bar $=20 \mu \mathrm{m}$. 
2,800 per $\mathrm{mm}^{2}$, very close to the body dermal glands $\left(1,800-2,000\right.$ orifices $\left./ \mathrm{mm}^{2}\right)$. In $\mathrm{T} 10$, glandular orifices were open in variable depressions, 2 to 25 orifices/depression (Figs 3, 7) and concentrated on the anterior part of the pygidium. Each glandular orifice was about $0.6 \mu \mathrm{m}$ in diameter. There were approximately 2,900 depressions on average and 20,000 glandular orifices per $\mathrm{mm}^{2}$. This anterior region of the pygidium was undulating and slacking (Fig. 7) and normally covered by tergite 9. This overlap is identical to that observed in $S$. lampyridiformis as illustrated in Fig. 12. The release of sex pheromone during the calling period can be enhanced by expanding the slack zone to expose the glandular orifices situated anteriorly on the pygidium. The glandular epithelium was made up of type 3 glandular cells (one secretory cell + one canal cell) as revealed with transmission electron microscopy. The ductule and end-apparatus were observed (Fig. 4). After the cellular tissues were removed by a $\mathrm{KOH}$ digestion, a large number of long cuticular ducts were observed underneath the cuticle (Fig. $5)$. In the posterior zone of the pygidium there were poorly developed gland units where ducts and endapparatus were single, unbranched hollow tubes approximately $80 \mu \mathrm{m}$ in length with one end inserted into the cuticle (Fig. 6).

Male tergal glands. Males have two tergal glands located on tergites T1 and T2 with surface areas of about $8.5 \mathrm{~mm}^{2}$ and $3 \mathrm{~mm}^{2}$ respectively. The density of glandular orifices was variable on each tergite and contained about 6,600 and 7,100 orifices $/ \mathrm{mm}^{2}$ in $\mathrm{T} 1$ and $\mathrm{T} 2$, respectively. On T2, glandular orifices were open in small depressions with 3 to 11 orifices per depression (Figs 13, 14). With the scanning electron microscopy, sculpturing on the cuticular surface appeared as plaques or scales with many small depressions, containing glandular orifices in between (Fig. 13). Some depressions contained secretions resembling mushrooms growing from glandular orifices (Fig. 14). It should be noted that on T1, there were two specific zones that I named "differentiated glandular areas" on the exterior lateral of the tergite near the zone with numerous sensilla (Fig. 15). These two zones, about $0.9 \mathrm{~mm}^{2}$ in size, each contained numerous glandular depressions with 3 to 36 glandular orifices/depression (Fig. 16). They averaged about 11,000 glandular orifices per $\mathrm{mm}^{2}$.

\section{Blaberus colosseus}

Female pygidial gland. The female has the pygidial gland on the anterior zone of T10 covering a $2.1 \mathrm{~mm}^{2}$ surface area. Glandular orifices were open in depressions of variable size with $2-40$ orifices/depression. Each orifice was $0.6 \mu \mathrm{m}$ in diameter. There were approximately 5,200 depressions and 38,000 orifices per $\mathrm{mm}^{2}$. The entire female pygidial gland contained about 80,000 glandular orifices.

Male tergal glands. Male tergal glands were situated on tergites $\mathrm{T} 1$ and $\mathrm{T} 2$. There were about 8,400 glandular orifices $/ \mathrm{mm}^{2}$ on $\mathrm{T} 1$ and 4,900 orifices $/ \mathrm{mm}^{2}$ on T2. On T1, the glandular orifices were individually separated but on T2, they were grouped in small depressions with 2-5 orifices/depression. On T3 and T4, there were about 2,600 orifices $/ \mathrm{mm}^{2}$, very close to dermal glandular ori-

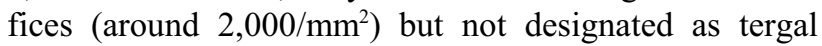
glands.

\section{Blaberus craniifer}

Female pygidial gland. The female has pygidial glands located on the anterior zone of T10 covering a $1.8 \mathrm{~mm}^{2}$ surface area. Glandular orifices were open in depressions of variable size with $2-23$ orifices/depression. The cuticular surface of the anterior zone containing numerous glandular orifices was very undulating and slack (Figs 8, 9). Each glandular orifice had an average diameter of $0.7 \mu \mathrm{m}$. There were approximately 3,100 depressions and 27,000 orifices per $\mathrm{mm}^{2}$. The entire female pygidial gland contains about 48,000 glandular orifices.

Male tergal glands. The males have two tergal glands located on tergites $\mathrm{T} 1$ and $\mathrm{T} 2$, the mean surface area of each tergite being about $22 \mathrm{~mm}^{2}$. Glandular orifices were much more abundant on T1 totalling on average about 10,000 orifices $/ \mathrm{mm}^{2}$, whereas, on $\mathrm{T} 2$, the average was about 4,300 orifices $/ \mathrm{mm}^{2}$. On T1, glandular orifices of variable diameter size $(0.25-0.3 \mu \mathrm{m})$, were solitary or grouped 2-4 (Figs 17, 18). On tergite 2, small glandular orifices were open on the cuticular surface revealing very distinct scutes with one spine (Fig. 19).

\section{Blaberus discoidalis}

Female pygidial gland. The females have pygidial glands located on the anterior zone of T10 covering a 2.1 $\mathrm{mm}^{2}$ surface area, such as in $B$. colosseus. The glandular orifices were open in depressions of variable size with 2 to 28 orifices/depression. Each glandular orifice has an average diameter of $0.5 \mu \mathrm{m}$ and there are approximately 3,000 depressions and 31,000 orifices per $\mathrm{mm}^{2}$. The entire female pygidial gland contains approximately 65,000 glandular orfices.

Male tergal glands. Males have two tergal glands situated on tergites $\mathrm{T} 1$ and $\mathrm{T} 2$ covering an average area of about 14 and $12 \mathrm{~mm}^{2}$, respectively. There were an average of 9,400 glandular orifices $/ \mathrm{mm}^{2}$. On $\mathrm{T} 1$ there were two specific zones or "differentiated glandular areas" on the exterior lateral of the tergite, near the zone with numerous sensilla as in the $B$. fumigata male. These two zones occupy an average surface area of about 0.5 $\mathrm{mm}^{2}$ each and contain many glandular depressions with 3 to 30 orifices/depression as in the pygidial gland of the female. There were about 12,000 glandular orifices per $\mathrm{mm}^{2}$.

\section{Blaptica interior}

Female pygidial gland. The female pygidial gland was situated on the anterior zone of T10 covering about 0.8 $\mathrm{mm}^{2}$ of glandular area. The histological section of T9 and T10 indicated that the glandular epithelium on the anterior zone of T10 was developed and composed principally of two cell layers. This glandular region with depressions on the cuticle covering the gland containing cuticular ducts, was completely covered by $\mathrm{T} 9$. The glandular orifices were open in depressions of variable size containing 

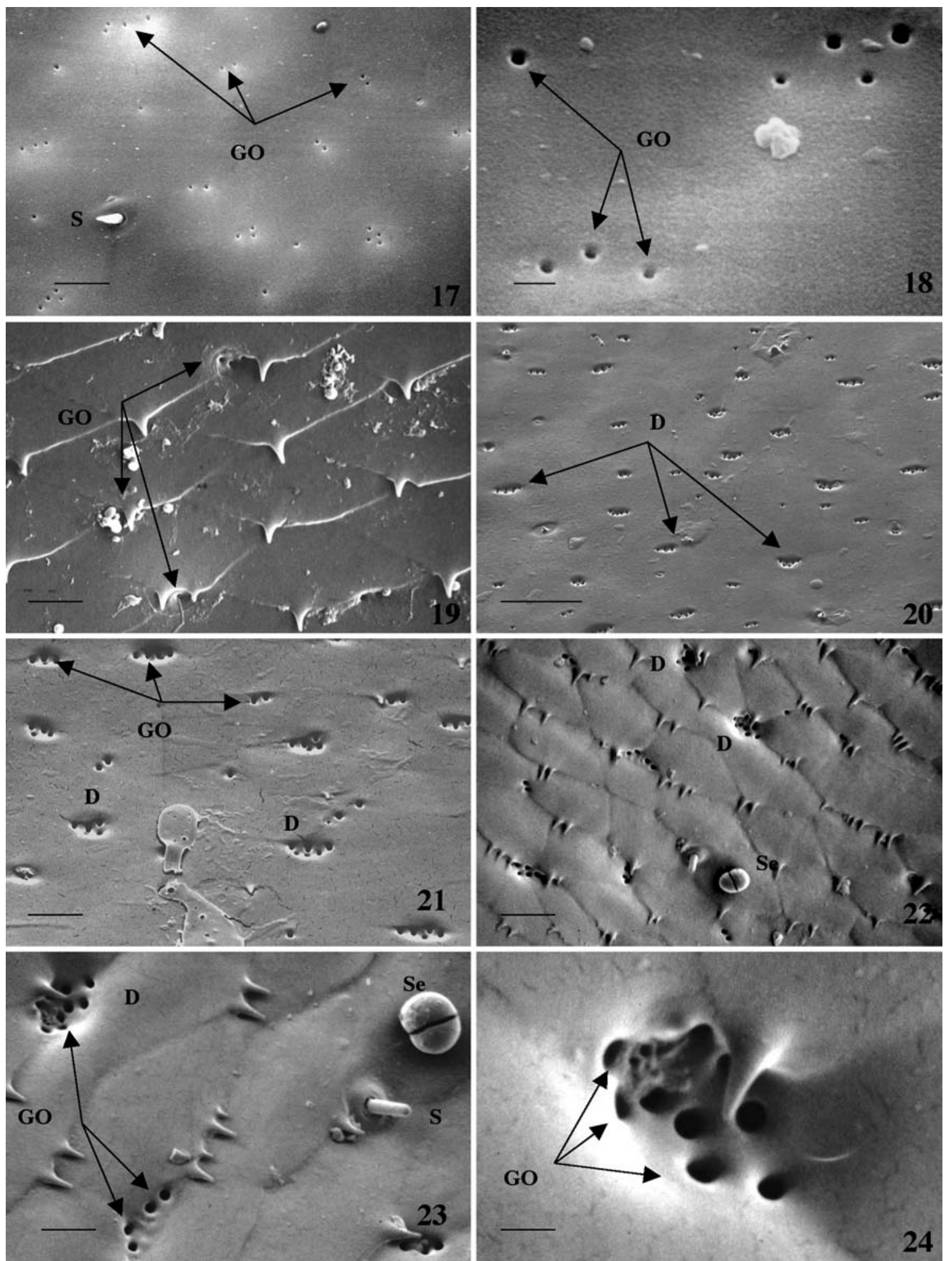

Figs 17-24. 17-19: Blaberus craniifer male. General appearance of T1's tergal gland. GO = glandular orifices; $\mathrm{S}=$ setae. $\mathrm{Bar}=5$ $\mu \mathrm{m} .18$ - detail of some glandular orifices (GO) showing the variability of diameter size. Bar $=2 \mu \mathrm{m} .19-$ general appearance of T2's tergal gland. $\mathrm{GO}=$ glandular orifices. Bar $=4 \mu \mathrm{m} .20-24$ : Blaptica interior male. $20-$ tergal gland of T6 showing numerous small depressions (D) containing glandular orifices. Bar $=20 \mu \mathrm{m} .21$ - detail of T6's tergal gland. D = depression; GO = glandular orifices. Bar $=4 \mu \mathrm{m} .22$ - general appearance of tergal gland of T2 showing numerous small glandular orifices in depressions (D); $\mathrm{Se}=$ secretion. $\mathrm{Bar}=6 \mu \mathrm{m} .23-$ detail of preceding figure 22 showing numerous small glandular orifices (GO) in depression (D). S $=$ setae; $\mathrm{Se}=$ secretion. $\mathrm{Bar}=3 \mu \mathrm{m} .24-$ seen under greater magnification, the glandular orifices (GO) open out at the bottom of cuticular depression. Bar $=1.5 \mu \mathrm{m}$. 
TABLE. 1. Abdominal exocrine glands, tergal glands $(\mathrm{X})$ in females and males of seven species of Blaberinae (Bn), one species of Epilamprinae (En), one species of Panestiinae (Pn) and one species of Zetoborinane $(\mathrm{Zn}) . \mathrm{X}=$ glandular orifices in abundance $; \mathrm{x}=$ glandular orifices less abundant $; \mathrm{X}^{*}=$ glandular orifices in abundance associated with "Differentiated glandular areas" of T1; $\mathrm{T}=$ tergite; ? = no specimen available.

\begin{tabular}{|c|c|c|c|c|c|c|c|c|c|}
\hline \multirow{2}{*}{ Species } & \multicolumn{2}{|c|}{ Female tergites with glands (X) } & \multicolumn{7}{|c|}{ Male tergites with glands $(\mathrm{X})$} \\
\hline & $\mathrm{T} 9$ & $\mathrm{~T} 10$ & $\mathrm{~T} 1$ & $\mathrm{~T} 2$ & $\mathrm{~T} 3$ & $\mathrm{~T} 4$ & $\mathrm{~T} 5$ & T6 & $\mathrm{T} 7$ \\
\hline Blaberus colosseus $(\mathrm{Bn})$ & & $\mathrm{X}$ & $\mathrm{X}$ & $\mathrm{X}$ & & & & & \\
\hline Blaberus craniifer $(\mathrm{Bn})$ & & $X$ & $\mathrm{X}$ & $\mathrm{X}$ & & & & & \\
\hline Blaberus discoidalis (Bn) & & $\mathrm{X}$ & $\mathrm{X}^{*}$ & $\mathrm{X}$ & & & & & \\
\hline Blaptica interior $(\mathrm{Bn})$ & & $X$ & $\mathrm{X}^{*}$ & $\mathrm{X}$ & $X$ & $\mathrm{X}$ & $\mathrm{X}$ & $\mathrm{X}$ & $\mathrm{X}$ \\
\hline Byrsotria fumigata $(\mathrm{Bn})$ & $\mathrm{x}$ & $\mathrm{X}$ & $\mathrm{X}^{*}$ & $\mathrm{X}$ & & & & & \\
\hline Epilampra maya $($ En $)$ & & $X$ & $?$ & $?$ & & & & & \\
\hline Eublaberus distanti $(\mathrm{Bn})$ & $\mathrm{X}$ & $X$ & $\mathrm{X}$ & $\mathrm{X}$ & & & & & \\
\hline Eublaberus posticus (Bn) & & $\mathrm{X}$ & $X^{*}$ & $\mathrm{X}$ & $\mathrm{X}$ & $\mathrm{x}$ & $\mathrm{x}$ & $\mathrm{x}$ & $\mathrm{x}$ \\
\hline Panesthia sp. (Pn) & & $X$ & $?$ & $?$ & & & & & \\
\hline Schultesia lampyridiformis $(\mathrm{Zn})$ & & $\mathrm{X}$ & $\mathrm{X}$ & $\mathrm{X}$ & $\mathrm{X}$ & $\mathrm{X}$ & & & \\
\hline
\end{tabular}

one to 15 orifices/depression, each orifice having an average diameter of $0.8 \mu \mathrm{m}$. There were approximately 4,700 depressions and 31,000 glandular orifices per $\mathrm{mm}^{2}$ (Figs 10,11).

Male tergal glands. Male tergal glands were situated on the first seven abdominal tergites and covered an average surface area of about $8 \mathrm{~mm}^{2}$ for T1 and about $3.5 \mathrm{~mm}^{2}$ for other tergites. On the central regions of each tergite, the number of glandular orifices remained relatively constant and averaged 8,600,8,700,8,000 and 6,000 orifices per $\mathrm{mm}^{2}$ for T1, T2, T6 and T7, respectively. On T6, two to ten glandular orifices were open in small depressions (Figs 20 and 21). On T2, the cuticular surface appeared as plaques or scales, each with one to four "spines" on the posterior edge, between which were many small depressions containing two to ten glandular orifices. Sensory setae were present (Figs 22 and 23) and each orifice had an average diameter of $0.25 \mu \mathrm{m}$. (Fig. 24). On T1 there were two specific zones or "differentiated glandular areas" on the exterior lateral of the tergite near the zone with numerous sensory setae as in the $B$. fumigata and $B$. discoidalis male. These two zones, about $0.65 \mathrm{~mm}^{2}$ each contained numerous glandular depressions with two to twelve orifices/depression. There were about 11,000 glandular orifices per $\mathrm{mm}^{2}$.

\section{Epilampra maya}

Female pygidial gland. Female has pygidial glands situated on the anterior zone of T10 covering about $0.9 \mathrm{~mm}^{2}$ of glandular area. The glandular orifices were scarce, opened in small depressions with 2-5 glandular orifices per depression and numbered approximately 7,000 orifices per $\mathrm{mm}^{2}$.

Male tergal glands. Male specimens of this species were not available.

\section{Eublaberus distanti}

Female pygidial glands. The female has pygidial glands on the anterior zone of T9 and T10 covering about 0.6 $\mathrm{mm}^{2}$ and about $3 \mathrm{~mm}^{2}$ of glandular area respectively. On
T9, two glandular regions were arranged symmetrically delimiting two distinct areas on the anterior part of the tergite with regard to the mid-dorsal line. The glandular orifices were open in depressions of variable size, the number ranging from two to ten according to the size of the depression and each having an average diameter of $0.7 \mu \mathrm{m}$. The number averaged 3,600 depressions and 13,000 glandular orifices per $\mathrm{mm}^{2}$. On the anterior zone of T10, the glandular area was about $0.5 \mathrm{~mm}$ wide and 6 mm long (approx. $3 \mathrm{~mm}^{2}$ ). The orifices were open in variably sized and generally large depressions. The number ranged from 2 to 28 orifices per depression and averaged 26,000 glandular orifices per $\mathrm{mm}^{2}$. The female contains about 77,000 and 8,000 glandular orifices on $\mathrm{T} 10$ and $\mathrm{T} 9$, respectively.

Male tergal glands. The male tergal glands were situated on the first two abdominal tergites, T1 and T2 with approximately 6,000 and 4,800 glandular orifices per $\mathrm{mm}^{2}$ respectively and covered an average surface area of $25 \mathrm{~mm}^{2}$ for each tergite. The glandular orifices were open in small depressions and contained two to four orifices per depression.

\section{Eublaberus posticus}

Female pygidial gland. The female pygidial gland is situated on the anterior region of T10 covering a $0.9 \mathrm{~mm}^{2}$ area and is less developed than in other species. The glandular orifices were open in variable depressions which contained two to twelve per depression. There were approximately 1,400 depressions and 8,000 orifices per $\mathrm{mm}^{2}$.

Male tergal glands. Male tergal glands are situated on the first seven abdominal tergites and cover an average surface area of about $12 \mathrm{~mm}^{2}$ each or an $85 \mathrm{~mm}^{2}$ total area. The density of glandular orifices varied on each tergite and decreased progressively from anterior to posterior. There were approximately 5,600, 3,800, 3,000, 2,500 and 2,300 glandular orifices on T1, T2, T3, T6 and T7, respectively. On $\mathrm{T} 1$, there were also two specific zones or "differentiated glandular areas" on the exterior lateral of 
the tergite near the zone with numerous sensilla, as in T1 of the $B$ fumigata, B. discoidalis and B. interior (Fig. 15). These two zones with a surface area of about $0.8 \mathrm{~mm}^{2}$ each were open small depressions containing very small glandular orifices ranging from 3 to 36 per depression (Fig. 16). Each glandular orifice has an average diameter of $0.3 \mu \mathrm{m}$ and there are on average about 11,000 per $\mathrm{mm}^{2}$.

\section{Panestia $\mathrm{sp}$}

Female pygidial gland. Female possesses the pygidial gland on the anterior zone of T10 covering a $2 \mathrm{~mm}^{2}$ surface area. On T10, glandular orifices were open in depressions of variable size with $2-8$ orifices/depression. Each orifice was $0.6 \mu \mathrm{m}$ in diameter and there were approximately 2,500 depressions and 10,000 glandular orifices per $\mathrm{mm}^{2}$.

Male tergal glands. Male specimens of this species were not available.

\section{Schultesia lampyridiformis}

Female pygidial gland. The female pygidial gland is on the anterior region of T10 covering about $0.6 \mathrm{~mm}^{2}$ of the glandular area. In the histological longitudinal section of T9 and T10, the glandular epithelium was located on the anterior part of T10 and covered completely by the posterior zone T9. The secretory epithelium (20-50 $\mu \mathrm{m}$ thick) is composed of two cell layers, mainly glandular and canal cells. The cuticle covering the gland averages $9 \mu \mathrm{m}$ in thickness and has depressions containing glandular orifices (Fig. 12), each having an average diameter of 0.8 $\mu \mathrm{m}$.

Male tergal glands. Male tergal glands are situated on the first four abdominal tergites, about $4 \mathrm{~mm}^{2}$ for $\mathrm{T} 1$ and $3 \mathrm{~mm}^{2}$ for other tergites. On the central regions of each tergite, the number of glandular orifices remains relatively high and averages approximately 6,000 orifices per $\mathrm{mm}^{2}$.

\section{DISCUSSION}

Our results here show that female pygidial glands are located posteriorly on the abdomen and male tergal glands generally on the tergites anteriorly. The occurrence of these glands in both females and males suggests the existence of two principal chemical signals: volatile sex attractant pheromone and male aphrodisiac and gives coherent explanations on sexual behaviors of many species of Blaberinae described previously by several authors (Barth, 1961a, 1964, 1968; Grillou, 1973; Moore \& Bath, 1976; Roth, 1968, 1969, 1970b; Roth \& Barth, 1967). In female $B$. fumigata, a tentative identification of pheromone sites was undertaken (Moore \& Barth, 1976). In these previous studies, because of data paucity on the pheromone sites producing chemical signals in females and males, the relationship between behavior, chemical signals and glands was not clearly established.

In many species where females emitted sex attractant pheromone and males aphrodisiac, female pygidial or tergal glands and male tergal glands were found in several groups : Blaberinae (results here), Blattellinae (Blattelli- dae), Polyphaginae (Polyphagidae) (as Cryptocercus punctulatus) (Grandcolas \& Deleporte, 1992) and Blattinae (Sreng, 1983, 1984). Willis (1970) suggested that "calling may be a behavior by which sexually active females disperse their pheromone", but in many cases pheromone gland sites were unknown. Pheromone liberation was accomplished by the calling posture exposing glandular regions, usually protected or hidden by the overlapping preceding segment. This is the typical situation of female pygidial glands studied here. The close relationship between release of pheromone and glands demonstrates that calling posture may indicate perfectly gland location in the body and vice versa. My previous proposition deals with pygidial glands as pheromone sites in females of many cockroach species, particulary in $B$. germanica and B. craniifer (Sreng, 1983). Female calling behavior of $B$. germanica and $B$. craniifer exposing pygidial glands was observed ten years later (Abed et al., 1993c; Liang \& Schal, 1993a). In E. maya and some Xestoblatta species (Blattellinae), typical calling females appear to raise their wings in a manner similar to that of courting males and lower their abdomen towards the substrate (Schal \& Bell, 1985). Pygidial glands were present in female E. maya and in female Xestoblatta (Sreng, unpubl. data). Previous studies showed that virgin females of many cockroach species, assumed calling behaviors, releasing sex attractant pheromones (Willis, 1970; Schal \& Bell, 1985; Hales \& Breed, 1983; Liang \& Schal, 1993a; Smith \& Schal, 1991; Gemeno et al., 2003) but the sources were rarely known or very controversial as in $P$. americana. In Blattellidae, glands were found on the pygidium of female B. germanica (Dusham, 1918) and Xestoblatta, on tergites T4 and T5 of S. longipalpa (Schal et al., 1992) and on tergites T6 and T7 of female Parcoblatta fulvescens (Sreng, 1983). The seventh tergites of $P$. lata and $P$. caudelli seem to be the source of pheromone (Gemeno et al., 2003). In the C. punctulatus female tergal glands were observed on the anterior part of $\mathrm{T} 7$ (Sreng, 1983). In the $P$. americana female, it was reported that the midgut (Bodenstein, 1970) or the atrium glands composed of type 1 cells (Abed et al., 1993b) or the colon (Yang et al., 1998) contain the highest pheromone activity. However, the location of the welldeveloped gland, which I called "the vestibulum gland" was situated on the terminal lobe of Sternum VII (at the level of vestibulum) and the glandular epithelium was composed mainly of type 3 gland cells as found in other cockroach gland cells (Sreng, unpubl. data). The same feature of vestibulum glands was found in female Blatta orientalis (Sreng, unpubl. data) and probably other Periplaneta species. Abed et al. (1993a) claimed that "the $B$. orientalis male adopts a calling behavior, attracts the female, and releases sexual behavior. This is the first report of a male sex pheromone in Blattidae" and contradicts results of other close species of the Blattinae subfamily, previous data established by several authors (Barth, 1970; Simon \& Bath, 1977a, b; Warthen et al., 1983; Seelinger, 1985) and also my own observations (Sreng, unpubl. data). It seems probable that their obser- 
vations were realised in a confined aquarium, saturated with pheromone compounds and, therefore, insect behavior, due to a saturated odor environment, may have been disorientated.

As for females, our results show that pygidial glands were present in all females of four Blaberidae subfamilies studied. These glandular orifices were generally present in the anterior zone of the $10^{\text {th }}$ tergite or pygidium and open in most variable sized depressions. The number of glandular orifices per $\mathrm{mm}^{2}$ was very high among insects such as B. colosseus, B. discoidalis, B. interior and E. distanti. In B. fumigata and $E$. distanti, in addition to the $10^{\text {th }}$ tergite, females possess glandular orifices on T9 which are less developed than pygidial glands. On T9 of $B$. fumigata, individually open glandular orifices were less abundant than pygidial glands but much more so than dermal glands not inside the depressions. In E.distanti, T9 has two small glandular regions on the anterior part of the tergite and the glandular orifices were open inside the depressions, but their number per $\mathrm{mm}^{2}$ was reduced by half in comparison to pygidial glands. The reduction of glandular orifice numbers, regions or segments was emphasized as a reduction tendency in the evolution process. The glandular orifice openings inside depressions seem to be a characteristic feature of glandular regions. They may be the original female pygidial gland form because these structures were found in all species of the four subfamilies studied here, in B. germanica and Xestoblatta. On T9, the glandular area and feature of these two species, E. distanti and B. fumigata could be considered as intermediate and reduction stages and suggest that gland reduction may occur prior to their being lost completely. These may represent relics of a glandular area that was situated on these anterior segments. All these facts suggest that a shift from the anterior to posterior position occurred, as the glandular segments in almost all species studied have evolved to a posterior position on only one segment, the pygidium.

The posterior location of glands on the abdomen tip seems to be better adapted for calling and physiological regulation in pheromone liberation. This appears to reach stability in Blaberinae, probably Zetoborinae, Epilamprinae and Panesthiinae and also in some species of Blattellidae such as B. germanica or Xestoblatta, of Polyphaginae as $C$. punctulatus, of Blattinae as Periplaneta or Blatta. In the C. punctulatus female, tergal glands were present on the anterior part of the large tergite 7, overlapping the small tergites 8,9 and 10 (Sreng, 1983). This T7 located posteriorly on the tip of the female abdomen, notably resembled pygidium in other species.

As for males, in type A pattern, the male wing-raising behavior, exposing tergal regions was associated with the release of aphrodisiacs and accompanied generally by female mounting and feeding behavior, before mating occurred. Male wing-raising was intimately linked with exposing tergal glands and in many cases these glands were unknown. The robust comparative framework of male tergal glands in Blattaria has been enhanced by the studies of Roth (1969). He stated that "male tergal glands serve to manoeuvre the female into the proper precopulatory position and arrest her movement...". Male wingraising behavior was always linked with the presence of male tergal glands in species where tergites show no modifications, species within Oxyhaloinae (Sreng, 1984), Blaberinae, and male Diploptera punctata (Diplopterinae) (T1 to T5), Pycnoscelus indicus (Pycnoscelinae) (T2 to T7), P. fulvescens (T1 to T4), C. punctulatus (T8), $P$. americana (T2 to T4) and B. orientalis (T2 to T9) (Sreng, 1983). Our results show that male Blaberinae possess well-developed tergal glands and show no visible external segment modification. These tergal glands were generally situated on anterior tergites (T1 and T2) except in B. interior and $S$. lampyridiformis. This glandular location in males rejoins Roth's statement (1969): "From the position assumed by the female prior to copulation, the best site for the location of tergal glands restricted to segments would be anterior, near the base of the wings. When the female's head was in this position, the genitalia of both sexes were close together and this would make it easier for coupling to occur". This ideal hypothetical postulation seems to occur in male tergal glands on T1 and T2 of $B$. craniifer, B. colosseus, B. discoidalis, B. fumigata, E.distanti and E. posticus. In B. interior, E. posticus and $S$. lampyridiformis, tergal glands were present on more than two tergites. In E. posticus, the number of glandular orifices decreased gradually from anterior tergites $\mathrm{T} 1$ to $\mathrm{T} 7$. As the number of glandular orifices per $\mathrm{mm}^{2}$ was low from T4 to T7, scarcely much more than dermal glands, I do not consider them to be glandular. This could be considered as an intermediate stage between species with fully developed glandular tergites, such as $B$. interior, and species that reached stability in the reduction process in $\mathrm{T} 1$ and T2 only, as B. colosseus, B. craniifer or B. fumigata. Blaberinae male tergal glands suggest that a shift from a posterior to anterior position has occurred. The presence of two differentiated regions of $\mathrm{T} 1$, near the setae area in $B$. discoidalis, B. fumigata, B. interior and $E$. posticus was emphasized. These special areas show a very small size of open glandular orifices in the depressions, and look like those in female pygidial glands which contain numerous glandular orifices. Glandular location was situated outside of the median line of the tergite where right and left antennae are able to reach enabling the female to lick the tergal back. These external differentiated glandular regions associated with the setae area were probably used as an aphrodisiac chemical beacon for females, a contact stimulation and female position detection by males. Thus, enabling the male to detect the exact position of the female on his back when her head was at the base of his wings, during the licking behavior on the central line glandular area of $\mathrm{T} 1$. These regions probably secreted more volatile compounds, served as a chemical marker for females and had an excitatory effect on mating success.

The stability in posterior location of female pygidial glands and anterior male tergal glands in the Blaberinae was also reflected in other characteristics, namely, similarities in reproductive systems (Roth, 1970a), female and 
male genitalia and morpho-anatomical characteristics (McKittrick, 1964; Roth, 1970c; Grandcolas, 1996). More data on pheromone glands in other cockroach groups is needed to enhence our understanding of gland location, sexual behavior, chemical composition of sex pheromones and their co-evolutionary significance. Therefore, some of the descriptions which indicated the absence of, or do not mention, tergal, pygidial or related glands with glandular orifices, may need revision when additional specimens are studied.

The interspecific mating in Blattaria was investigated by Roth (1970b) and showed that no mating occurred between species of four genera (Blaberus, Byrsotria, Eublaberus and Archimandrita) of Blaberinae, but several took place among four species of Blaberus and five species of Blattella. In an effort to understand the interspecificity of the pheromone effect on different species, Barth (1961a, 1970), using female sex pheromone of several genera and species of cockroaches, found that female sex pheromone of $P$. americana would excite males of $P$. brunea, $P$. fuliginosa and $B$. orientalis (Blattinae), but not Eurycotis floridana (Polyzosteriinae), B. fumigata, Leucophaea (Rhyparobia) maderae (Oxyhaloinae) and $N$. cinerea. The female pheromone of $B$. fumigata elicited a positive response from the $B$. craniifer male, a weak response from that of $B$. giganteus, but none from that of $P$. americana. The pheromone of $B$. craniifer stimulated males of B. fumigata. Barth (1961a, 1970) concluded that "within the Blaberinae, the female sex pheromone of $B$. fumigata, B. craniifer and B. giganteus were interspecifically effective in releasing male courting behavior in all combinations tested". These observations on interspecific mating and pheromone interattraction in the same Blaberinae species corroborate our results, showing the uniform presence of female pygidial and male tergal glands in these species. Some sex pheromone and aphrodisiac components of pygidial and tergal glands may be common to species such as Oxyhaloinae, using seducin compounds (Roth \& Dateo, 1966; Sreng, 1990), the "Seducin group", such as Blattinae using Periplanone compounds (Persoons et al., 1990; Takegawa \& Takahashi, 1989; Ho et al., 1992) or the "periplanone group". In S. longipalpa and B. germanica, only one compound in each species of female sex pheromone was chemically identified (Charlton et al., 1993; Nojima et al., 2005) and no common substance was found. The unique pheromone compound identified in these two species seems to be special to Blattaria and other insects, in particular, moth species (Arn et al., 1992).

Therefore, pheromone compounds and glands appear to be the best markers during evolutionary behavioral changes. In the Oxyhaloinae subfamily (Roth, 1971), the occurrence of three mating behavioral patterns in very close species was striking (Sreng, 1983, 1984, 1992, 1993). Changes in the mating sequence appear to be related to the aphrodisiac emission system, which involves changes in the tergal glands. In type A mating, the tergal glands which were licked by females were well developed, whereas in types $\mathrm{B}$ and $\mathrm{C}$, there was no male tergal licking, and the tergal glands were markedly reduced. In Gromphadorhina laevigata (type C pattern), gas chromatography coupled with a mass spectrometry analysis (GC-MS) of abdominal glands showed that the three compounds found in sex pheromone of N.cinerea (type A pattern), were present in equal proportions in tergal and sternal glands of G. laevigata (Sreng, 1994). Actually, Roth \& Dateo (1966) noted that extracts from males of Gromphadorhina were highly attractive to females of $N$. cinerea. From this interattraction between the same groups of different species, it was clear that one or more sex pheromone components may be common to each and comparable to those in the moth species (Schneider, 1966; Arn et al., 1992). The characteristics based on sex pheromone glands and chemical sex pheromone components provide grounds for understanding the species in which morphology and mating pattern criteria are unrecognisable, and establishing evolutionary relationships between chemical signals, abdominal glands and different patterns of mating behavior.

Histological and ultrastructural studies of cockroach female pygidial and male tergal glands show that these glands, formed mainly of type 3 cells are composed of two cells, i.e. glandular and canal cells that correspond to a single open orifice on the cuticle. Type 3 glandular cells were found in most cockroach exocrine glands (Plattner et al., 1972; Porcheron, 1973; Sreng, 1979a, 1984, 1985; Gupta, 1979; Tokro, 1984; Menon, 1986; Farine et al., 1989; Tokro et al., 1993; Liang \& Schal, 1993b; Quennedey \& Brossut, 1975; Brossut \& Sreng, 1980). All sexual glands in males or females exist only in adults and were differentiated before imaginal moult and reached their functional maturation 3-4 days after adult life. The differentiation process of these glands was in close relation to pheromone production (Sreng, 1985, 1998; Sreng et al., 1999). Barth (1961b, 1962, 1965, 1968) proposed that the production of female sex pheromone in B. fumigata and $P$. americana was controlled by corpora allata (CA). Because of lack of data on pheromone component quantitation, behavioral tests used by Barth (1962) to appreciate pheromone production in allatectomized females of B. fumigata were inadequate. In B.craniifer (Grillou, 1977), 90\% of the females which were allatectomized during the last larval instar, mate. Therefore pheromone release and receptivity appear without intervention of CA. In $N$. cinerea, performing decapitation and allatectomy just after imaginal moult and before the critical period (3-4 days) after moulting during the maturation period precluded the apoptosis process that is necessary for gland maturation, but does not stop pheromone production since immature glands produce sex pheromone at a lower rate. JH injections stimulated pheromone production in both allatectomized and decapitated males but did not recover glandular maturation, which would suggest that JH stimulation may act as a doping effect. When decapitation was performed three to four days after the imaginal moult, no difference in pheromone production was observed in comparison with normal males. Brainderived factors involved in differentiation and pro- 
grammed cell death were crucial in the maturation process, pheromone production in N. cinerea (Sreng, 1998; Sreng et al., 1999) and probably in many other cockroach species.

During the evolution of cockroaches, some characteristics underwent profound modifications, but others persisted. The preceding description and discussion implies that among cockroaches, sex pheromone and aphrodisiac glands share the same type 3 gland cells, with similarity in differentiation mechanisms and maturation processes governing pheromone production. Close relationships between behavior and chemical signal liberation regulation, presented in similar cockroach groups showed uniformity in abdominal location, cellular structural organization and pheromone component composition. This suggests that pheromonal glands and probably pheromone components showing slow modificational changes during their evolution, constitute criteria or clues for the identification of groups or related species.

ACKNOWLEDGEMENTS. I thank D. van Kol for her help in the correction of the English manuscript, L.M. Roth, U.S. Natick Laboratories, Natick, Massachusetts, for his generous offering of species analysed in this study, S. Nitsche for SEM technical assistance and three anonymous reviewers for their helpful comments and suggestions.

\section{REFERENCES}

Abed D., Farine J.P. \& Brossut R. 1993a: Evidence for sex pheromones produced by males and females in Blatta orientalis (Dictyoptera, Blattidae). J. Chem. Ecol. 19: 2831-2853.

Abed D., Cheviet P., Farine J.P., Bonnard O., Le Quéré J.L. \& Brossut R. 1993b: Calling behaviour of female Periplaneta americana: Behavioural analysis and identification of the pheromone source. J. Insect Physiol. 39: 709-720.

Abed D., Brossut R., Farine J.P. \& Tokro P.G. 1993c: Pheromone in Blattella germanica and Blaberus craniifer (Blaberoidea): glandular source, morphology and analyses of pheromonally released behaviours. Chemoecology 4: 46-54.

Arn H., Tóth M. \& Priesner E. 1992: List of Sex Pheromones of Lepidoptera and Related Attractants. 2nd ed. International Organisation for Biological Control, West Paleartic Regional, Montfavet, France, 179 pp.

BARth R.H. 1961a: Comparative and Experimental Studies on Mating Behavior in the Cockroaches. Ph.D Thesis, Harward University.

BARTH R.H. 1961b: Hormonal control of sex attractant production in the Cuban cockroach. Science 133: 1598-1599.

BARTH R.H. 1962: The endocrine control of mating behavior in the cockroach Byrsotria fumigata (Guérin). Gen. Comp. Endocrinol. 2: 53-69.

BARTH R.H. 1964: The mating behavior of Byrsotria fumigata (Guérin) (Blattidae, Blaberinae). Behaviour 23: 1-30.

BARTH R.H. 1965: Insect mating behavior: endocrine control of a chemical communication system. Science 149: 882-883.

BARTH R.H. 1968: The comparative physiology of reproductive processes in cockroaches. Part I. Mating behavior and its endocrine control. Adv. Reprod. Physiol. 3: 167-207.

BARTH R.H. 1970: The mating behavior of Periplaneta americana (Linnaeus) and Blatta orientalis Linnaeus (Blattaria, Blattinae), with notes on 3 additional species of Periplaneta and interspecific action of female sex pheromone. Z. Thierpsychol. 27: 722-748.
BeLl W.J. 1981: Pheromone and behavior. In Bell W.J. \& Adiyodi K.G. (eds): The American Cockroach. Chapman and Hall, London, pp. 371-397.

BodEnSTEIN W.G. 1970: Distribution of female-sex pheromone in the gut of Periplaneta americana (Orthoptera: Blattidae). Ann. Entomol. Soc. Am. 63: 336-337.

BRossut R. \& Roth L.M. 1977: Tergal modifications associated with abdominal glandular cells in the Blattaria. J. Morphol. 151: 259-298.

BRossut R. \& SRENG L. 1980: Ultrastructure comparée des glandes exocrines abdominales des Blattaria (Dictyoptera). Int. J. Insect Morphol. Embryol. 9: 199-213.

Charlton R., Webster F.X., Zhang A., Schal C., Liang D., SReng I. \& Roelofs W.L. 1993: Sex pheromone for the brownbanded cockroach is an unusual dialkyl-substituted a-pyrone. Proc. Nat. Acad. Sci. USA 90: 10202-10205.

Dusham E.H. 1918: The dorsal pygidial glands of the female cockroach, Blattella germanica. Can. J. Entomol. 50: 278-281.

EwING L.S. 1967: Fighting and death from stress in a cockroach. Science 155: 1035-1036.

Farine J.P., Brossut R. \& Nalepa C.A. 1989: Morphology of the male and female tergal glands of the woodroach Cryptocercus punctulatus (Insecta, Dictyoptera). Zoomorphology 109: $153-164$.

Gemeno C., Snook K., Benda N. \& Schal C. 2003: Behavioral and electrophysiological evidence for volatile sex pheromones in Parcoblatta wood cockroaches. J. Chem. Ecol. 29: $37-54$.

GrandCOLAS P. 1996: The phylogeny of Cockroach families: a cladistic appraisal of morpho-anatomical data. Can. J. Zool. 74: 508-527.

Grandcolas P. \& Deleporte P. 1992: La position systématique de Cryptocercus Scudder au sein des blattes et ses implications évolutives. C. R. Acad. Sci. Paris 315: 317-322.

Grillou H. 1973: A study of sexual receptivity in Blabera craniifer Burn. (Blattaria). J. Insect Physiol. 19: 173-193.

GrILlou H. 1977: Effect on apparition of sexual receptivity in Blaberus craniifer females (Blattaria) of allatectomy during the last larval instar. Biol. Behav. 2: 65-74.

GUPTA B.D. 1979: Abdominal tergal glands of the American cockroach, Periplaneta americana (L.) (Orthoptera: Blattidae). Fol. Morphol. 3: 203-214.

Hales R.A. \& Breed M.D. 1983: Female calling and reproductive behavior in the brown banded cockroach, Supella longipalpa (F). Ann. Entomol. Soc. Am. 76: 239-241.

Ho H.Y., Yang H.T., Kou R. \& Chow Y.S. 1992: Sex pheromone of the brown cockroach, Periplaneta brunnea Burmeister. I. Isolation. Bull. Inst. Zool. Acad. Sin. 31: 225-230.

Liang D. \& Schal C. 1993a: Calling behavior of the female German cockroach, Blattella germanica (Dictyoptera: Blattellidae). J. Insect Behav. 6: 603-614.

LiANG D. \& SCHAL C. 1993b: Ultrastructure and maturation of a sex pheromone gland in the female German cockroach, Blattella germanica. Tissue \& Cell. 25: 763-776.

Liang D. \& Schal C. 1993c: Volatile sex pheromone in the female German cockroach. Experientia 49: 324-328.

Martoja R. \& Martoja-Pierson M. 1967: Initiation aux Techniques de l'Histologie Animale. Masson et Cie, Paris, 345 pp.

McKitTrick F.A. 1964: Evolutionary studies of cockroaches. Mem. Cornell Univ. N. Y. Agric. Exp. Stat. 389: 1-197.

MenON M. 1986: Morphological evidence for a probable secretory site of the male sex pheromones of Nauphoeta cinerea (Blattaria, Blaberidae). 2. Electron microscope studies. $J$. Morphol. 87: 69-79. 
Moore J.K. \& Barth R.H. 1976: Studies on the site of sex pheromone production in the cockroach, Byrsotria fumigata. Ann. Entomol. Soc. Am. 69: 911-916.

NoIRot C. \& QuenNedey A. 1974: Fine structure of insect epidermal glands. Annu. Rev. Entomol. 19: 61-80.

Noirot C. \& QuenNedey A. 1991: Glands, gland cells, glandular units: some comments on terminology and classification. Ann. Soc. Entomol. Fr. 27: 123-128.

Nojima S., Schal C., Webster F.X., Santangelo R.G. \& RoeLOFS W.L. 2005: Identification of the sex pheromone of the german cockroach, Blattella germanica. Science 307: $1104-1106$

Persoons C.J., Ritter F.J., Verwiel P.E.J., Hauptmann H. \& Mori K. 1990: Nomenclature of American cockroach sex pheromones. Tetrah. Lett. 31: 1747-1750.

Plattner H., Salpeter M., Carrel J.E. \& Eisner T. 1972: Struktur und funktion des drusenepithels der postabdominalen tergite von Blatta orientalis. Z. Zellf. 125: 45-87.

Porcheron P. 1973: Les glandes tergales des blattes. Organisation générale de la glande tergale de Leucophaea maderae (Dictyoptera, Blaberoidea, Blaberidae, Oxyhaloinae). C. R. Acad. Sci. Paris 277: 77-79.

QUENNEDEY A. 1998: Insect dermal gland cells: ultrastructure and morphogenesis. In Harrison F.E. \& Locke M. (eds): Microscopic Anatomy of Invertebrates. Vol. 11A. Willey-Liss, New York, pp.177-207.

QuenNedey A. \& Brossut R. 1975: Les glandes mandibulaires de Blaberus craniifer Burm. (Dictyoptera, Blaberidae), développement, structure et fonctionnement. Tissue \& Cell 7: 503-517.

Rотн L.M. 1968: Reproduction of some poorly known species of Blattaria. Ann. Entomol. Soc. Am. 61: 571-579.

Rотн L.M. 1969: The evolution of male tergal glands in the Blattaria. Ann. Entomol. Soc. Am. 62: 176-208.

Rотн L.M. 1970a: Evolution and taxonomic significance of reproduction in Blattaria. Annu. Rev. Entomol. 15: 75-96.

Rотн L.M. 1970b: Interspecific mating in Blattaria. Ann. Entomol. Soc. Am. 63: 1282-1285.

Rотн L.M. 1970c: The male genitalia of Blattaria. IV. Blaberidae: Blaberinae. Psyche 77: 308-342.

Rотн L.M. 1971: The male genitalia of Blattaria. VI Blaberidae: Oxyhaloinae. Psyche 78: 84-106.

Rотн L.M. \& Batн R.H. 1967: The sense organs employed by cockroaches in mating behavior. Behaviour 28: 58-94.

Rotн L.M. \& Dateo G.P. 1966: A sex pheromone produced by males of the Cockroach Nauphoeta cinerea. J. Insect Physiol. 12: 255-265.

Rотн L.M. \& WiLLIS E.R. 1952: A study of cockroach behavior. Am. Midl. Nat. 47: 66-129.

Rотн L.M. \& WiLlis E.R. 1954: The reproduction of cockroaches. Smithson. Misc. Coll. 122: 1-49.

SCHAL C. 1982: Intraspecific vertical stratification as a matefinding mechanism in tropical cockroaches. Science 215: 1405-1407.

Schal C. \& Bell W.J. 1985: Calling behavior in female cockroaches (Dictyoptera: Blattaria). J. Kans. Entomol. Soc. 58: 261-268.

Schal C., Gauthier J.Y. \& Bell W.J. 1984: Behavioral ecology of cockroaches. Biol. Rev. 59: 209-254.

Schal C., Liang D., Hazarika L., Charlton R.E. \& Roelofs L.W. 1992: Site of pheromone production in Supella longipalpa (Dictyoptera: Blattellidae): Behavioral, electrophysiological and morphological evidence. Ann. Entomol. Soc. Am. 62: 176-208.
SCHNEIDER D. 1966: Chemical sense communication in insects. In Nervous and hormonal mechanisms of Integration. Social, Econ. Behav. Symp. 20: 273-297.

SeELINGER G. 1984: Sex-specific activity patterns in Periplaneta americana and their relation to mate-finding. Z. Thierpsychol. 65: 309-326.

SEelinger G. 1985: Interspecific attractivity of female sex pheromone component of Periplaneta americana. J. Chem. Ecol. 11: 137-148.

SimON D. \& BARTH R. 1977a: Sexual behavior in the cockroach genera Periplaneta and Blatta. I. Description aspect. Z. Thierpsychol. 44: 80-107.

SimON D. \& BARTH R. 1977b: Sexual behavior in the cockroach genera Periplaneta and Blatta. II. Sex pheromones and behavioral responses. Z. Thierpsychol. 44: 162-177.

Sмith A.F. \& Schal C. 1991: Circadian calling behavior of the adult female brown-banded cockroach, Supella longipalpa (F.) (Dictyoptera: Blattellidae). J. Insect Behav. 4: 1-14.

SRENG L. 1976: Les glandes tergales du mâle de Blattella germanica L. (Insecte, Dictyoptère). Ultrastructure, développement, chimie de la sécrétion. Thesis, University of Dijon.

SRENG L. 1979a: Ultrastructure et chimie de la sécrétion des glandes tergales du male de Blattella germanica L. (Dictyoptera: Blattellidae). Int. J. Insect Morphol. Embryol. 8: 213-227.

Sreng L. 1979b: Phéromones et comportement sexuel chez Nauphoeta cinerea (Olivier) (Insecte, Dictyoptère). $C . R$. Acad. Sci. Paris 289: 687-690.

SRENG L. 1983: Comportement sexuel et communication chimique chez les Blattes. Cas de Nauphoeta et des genres voisins. PhD Thesis, University of Dijon.

SRENG L. 1984: Morphology of the sternal and tergal glands producing the sexual pheromones and the aphrodisiacs among the cockroaches of the subfamily Oxyhaloinae. J. Morphol. 182: 279-294.

SRENG L. 1985: Ultrastructure of the glands producing sex pheromones of the male Nauphoeta cinerea (Insecta, Dictyoptera). Zoomorphology 105: 133-142.

SRENG L. 1990: Seducin, male sex pheromone of the cockroach Nauphoeta cinerea: Isolation, Identification and Bioassay. $J$. Chem. Ecol. 16: 2899-2912.

SRENG L. 1992: The evolution of cockroach mating behaviors correlated with sex pheromone glands. In Billen J. (ed.): Biology and Evolution of Social Insects. Leuven University Press, Leuven, pp. 223-226.

SRENG L. 1993: Cockroach mating behaviors, sex pheromones and abdominal glands (Blaberidae: Oxyhaloinae). J. Insect Behav. 6: 715-735.

SRENG L. 1994: Sex pheromones and abdominal glands are preserved during evolutionary changes in cockroach mating behaviors. In Lenoir A., Arnold G. \& Lepage M. (eds): Les Insectes Sociaux. 12th World Congress on Social Insects, Paris, Sorbonne, France. p. 523.

SRENG L. 1998: Apoptosis-inducing brain factors in maturation of an insect sex pheromone gland during differentiation. Differentiation 63: 53-58.

SReng L. \& QueNNEDEY A. 1976: Role of a temporary ciliary structure in the morphogenesis of insect glands. An electron microscope study of the tergal gland of male Blattella germanica L. (Dictyoptera, Blattellidae). J. Ultrastr. Res. 56: 78-95.

Sreng L. Leoncini I. \& Clement J.L. 1999: Sex pheromone regulation in the male Nauphoeta cinerea cockroach: Role of the brain extracts, corpora allata (CA) and juvenile hormone (JH). Arch. Insect Biochem. Physiol. 40: 165-172. 
Takegawa H. \& Takahashi S. 1989: Sex pheromone of the Japanese cockroach, Periplaneta japonica Karny (Dictyoptera: Blattidae). Appl. Entomol. Zool. 24: 434-440.

Tokro P.G. 1984: Les phéromones sexuelles chez Blattella germanica L. (Insecte, Dictyoptère). Sécrétion d'une phéromone volatile par le pygidium de la femelle. Thesis, University of Dijon.

Tokro P.G., Brossut R. \& Sreng L. 1993: Mise en évidence de la phéromone sexuelle chez les femelles de Blattella germanica L. Insect Sci. Appl. 14: 115-126.
Warthen J.D., Uebel E.C., Lusby W.R. \& Adler V.E. 1983: Investigation of a sex pheromone for the oriental cockroach, Blatta orientalis. J. Insect Physiol. 29: 605-609.

WILLIS E.R. 1970: Mating behavior of three cockroaches (Latiblattella) from Hondura. Biotropica 2: 120-128.

Yang H.T., Chow Y.S., Peng W.K. \& Hsu E.L. 1998: Evidence for the site of female sex pheromone production in Periplaneta americana. J. Chem. Ecol. 24: 1831-1843.

Received October 5, 2005; revised and accepted May 15, 2006 